\title{
Straffrättssystemets funktion vid familjevåldsbrott mot barn: problem, utgångspunkter, perspektiv och svar
}

\author{
Af Linda Gröning ${ }^{1}$
}

\begin{abstract}
This article discusses the functions and limitations of the criminal justice system in regard to preventing, combating and reacting to domestic violence against children. Domestic violence herein refers to acts of violence against children committed by someone with whom the child has a close personal relationship. The article aims to clarify and discuss problems at different institutional levels of the system: its function to adequately criminalise and legislate in the area of domestic violence, and its function to properly implement existing rules by means of investigation, adjudication and administration of punishment. In this discussion, the problem of domestic violence will be addressed from a system perspective that considers both the internal functional division of the criminal justice system and the function of this system in relation to agents that are external to it.
\end{abstract}

\section{Problem}

Temat för detta inlägg är straffrättssystemets funktion och begränsningar i fråga om att förebygga, bekämpa och reagera på familjevåld mot barn. Med »familjevåld mot barn« avses här våldshandlingar mot barn som begås av personer som står i en nära relation till barnet. ${ }^{2}$ Det rättsdogmatiska nedslagsfältet är den norska rätten.

Inlägget har ett brett anslag och kommer att fokusera på kriminalpolitiska och rättsprincipiella problemställningar. Fokus ligger, mera specifikt, på att klargöra problemställningar på systemets olika institutionella nivåer, ifråga om att adekvat kriminalisera och lagstifta om familjevåld och sedan genom efterforskning, domstolsprocess och straffverkställighet adekvat implementera existerande regler. I denna diskussion kommer familjevåldsproblematiken att belysas från ett systemperspektiv, som omfattar både straffrättssystemets interna funktion och dess funktionsfördelning med andra externa aktörer i familjevåldskontexten. ${ }^{3}$ Ett så-

* Title in English: Domestic violence and the functionality of the criminal justice system: Problems, perspectives and answers. 
dant perspektiv kan vara relevant att ha med sig för att diskutera mer partikulera problemställningar angående rättsliga och straffrättsliga åtgärder mot familjevåld.

Inlägget kan ses mot bakgrund av att familjevåld utgör ett stort, och alltför stort, samhällsproblem. Mycket tyder på att de medel som hittills tagits i bruk, däribland kriminalisering och straff, inte varit tillräckliga - och kanske inte heller optimala för att realisera värdet av barnets bästa. ${ }^{4}$

Familjevåld är dock, genom dess »lokalisering« i gränssnittet mellan rättens offentliga domän och familjens privata sfär, ett särskilt problematiskt fält i straffrätten. ${ }^{5}$ Familjevåld relaterar också till ett moraliskt komplext fält. I gråzonen mellan tydligt våld och moraliskt problematiska men kanske inte uppenbart brottsliga handlingar verkar familjevåld i vart fall vara föremål för en del kontroverser om straffrättens funktion. Inlägget kommer särskilt att inriktas på detta komplexa fält.

\section{Utgångspunkter}

\subsection{Rättsliga och straffrättsliga utgångspunkter}

Den rättspolitiska utgångspunkten för våldsbrott mot barn är tydlig: sådana kränkningar ska inte förekomma och måste förebyggas och bekämpas, ytterst genom användning av straff. ${ }^{6}$ Den internationella rätten förpliktar också Norge (och andra stater) att reagera på sådana kränkningar. FNs barnkonvention tar utgångspunkt i principen om barnets bästa och pålägger i artikel 19(1) staterna att vidta åtgärder för att skydda barn mot alla former av våld. ${ }^{7}$

I norsk rätt förbjuder barneloven $\S 30$, som stadgar om föräldraansvaret, alla former av våld, även om denna sker som ett led i barnuppfostran. ${ }^{8}$ Det är inte knutet några sanktioner direkt till bestämmelsen, men den kan få betydelse som tolkningsunderlag i straffsaker för vad som anses utgöra otillåtet våld. Norsk rätt är i viss mån oklar på relationen mellan barnelovens förbud och straffrättens utsträckning. En omdiskuterad dom utgörs härvid av Rt. 2005 s. 1567, som uttalar att »det ikke rammes av strl. § 228 første ledd om foreldre i oppdragelsesøyemed tildeler sine barn lettere klaps «. ${ }^{9}$ Oavsett om detta uttalande numera kan anses i strid med gällande straffrätt, pekar domen på den moraliskt problematiska gråxonen i familjevåld.

Familjevåldsbrott mot barn kan aktualisera flera olika straffrättsliga bestämmelser. De mest centrala finns i strl. § 219 om misshandel i nära relationer, strl. $\S \S 228-231$ om legemskrenkelser, strl. § 222 och § 227 om tvång och hot samt $\S 223$ om frihetsberövande. Den centrala bestämmelsen är strl. $\S 219$ som straffbelägger att »true, tvinge, begrense bevegelsefriheten til, utøve vold mot eller på 
annan måte krenke, grovt eller gjentatt mishandle [...]« en närstående i den personkrets som bestämmelsen uppräknar - däribland barn. ${ }^{10}$

De handlingsalternativ som omfattas täcker således de övergrepp som definieras i de bestämmelser i straffeloven som referats ovan om legemskrenkelser, tvång, hot och frihetsberövelse, och dessa bestämmelser konsummeras som huvudregel också av strl. § 219. ${ }^{11}$

I praxis har också barn som varit vittne till misshandel mot en omsorgsperson, men inte själv varit direkt utsatt för våldet, likväl ansetts personligen utsatt för familjevåldsbrott enligt strl. § 219, Rt. 2009 s. 9. Den indirekta konsekvens som en misshandel av barnets närstående har för barnet har således ansetts kunna representera en kränkning efter strl. $§ 219$, så att bestämmelsen ger barnet ett självständigt skydd. ${ }^{12}$

Ett krav för att strl. § 219 ska aktualiseras är att de handlingar som begåtts är grova eller upprepade. Bestämmelsen är framförallt avsedd att träffa misshandel eller kränkningar som pågår under längre tid, och ska också kunna fånga upp komplexiteten i familjevåldsbrott. Strl. § 219 omfattar därvid också handlingar som inte träffas av andra bestämmelser i straffeloven. Långvariga kränkningar som inte nödvändigtvis måste orsakat konkret psykisk eller fysisk skada har exempelvis framhävts i förarbeten och praxis. Rädslan för våld, och känslan av att leva under hot, har därvid ansetts kunna upplevas långt värre än enstaka våldshandlingar. ${ }^{13}$ Bestämmelsen kan dock också träffa en enstaka handling om denna kan anses som grov. ${ }^{14}$ Med andra ord träffar bestämmelsen både reella och potentiella psykiska och fysiska skador och har en relativt sett vid omfattning.

Brott enligt strl. § 219 straffas, vid normalgraden, med upp till 4 års fängelse. Vid grovt brott är straffet fängelse upp till 6 år. När den nye straffeloven träder i kraft höjs dock strafframarna väsentligt. Då kan grovt brott straffas med upp till 15 års fängelse och brott av normalgraden med upp till 6 års fängelse. ${ }^{15}$

Familjevåldsbrott, och särskilt grova överträdelser, är en högt prioriterad brottstyp för straffrättssystemets brottsbekämpande myndigheter. ${ }^{16}$ Uppfattningen om den allvarliga karaktären i familjevåldsbrott mot barn kommuniceras också av reglerna om åtal. Brott mot strl. § 219 är i detta avseende underlagt ovillkorligt offentligt åtal. Straffrättens allvarliga syn på familjevåldsbrott framgår också mera allmänt av de olika lagändringar som ägt rum de senaste åren, till fördel för en effektivare brottsbekämpning. Ett exempel finns i infogandet av strl. § $219 \mathrm{i}$ avvärjningsplikten i strl. $§ 139 .{ }^{17}$ De senaste årens rättsutveckling har också, såsom den nye straffeloven framhäver, uppvisat en tydlig tendens mot straffskärpning för familjevåldsbrott. 
Samtidigt syns i Norge nu en tendens att använda alternativa procedurer vid familjevåldsbrott, särskilt i form av konfliktrådslösningar. ${ }^{18}$ I straffverkställigheten verkar argument om barnets bästa också alltmer styrande som argument, exempelvis för att tillåta en straffdömd med barn att sona utanför fängelset. ${ }^{19}$ Dessa exempel betonar den »privata « dimensionen, och särskilt offrets intresse, och står i viss spänning till den mer allmänna tendensen mot strängare straff vid familjevåldsbrott. Denna komplexitet i familjevåldsbrottet ska nu beskrivas närmare.

\subsection{Familjevåldsbrottets särskilda karaktär}

I en diskussion om straffrättssystemets funktion i familjevåldskontexten är det viktigt att utgå från att familjevåld är ett särskilt komplext brott just för att det är lokaliserat i gränssnittet mellan det offentliga och det privata. Familjen har traditionellt betraktats som en autonom domän som ska vara fri från extern inblandning. För bara några decennier sedan ansågs också våld inom familjen vara en privatsak - och avskrevs ofta som »husbråk«.

Familjevåld har fortfarande en komplex karaktär, även om skiljelinjen mellan det privata och det offentliga har suddats ut och skydd mot våld numera ska realiseras i alla kontexter - och särskilt i familjen. Även om familjerelationer är starkt destruktiva så har det faktum att de existerar - som relationer - fortfarande betydelse när vi söker de mest optimala sätten att reducera familjevåld. Den som slår är typiskt sett också en far eller en mor eller någon annan som offret också ofta bryr sig om. Denna relationella komponent kan ses som en försvårande omständighet - våld sker i en kontext som präglas av beroende och sårbarhet. ${ }^{20}$ Men familjekontexten kan också - så som några decennier sedan ses som en rättfärdigande omständighet för att använda i vart fall »mildare« våld. Den kulturella komponenten är här av stor betydelse i ett allt mer flerkulturellt samhälle. Olika kulturer har olika ideer om barnuppfostran och ibland olika ideer om att använda våld i detta syfte. ${ }^{21}$ Familjevåldsbrottets särskilda karaktär, i relation till andra typer av våldsbrott, kan också mer allmänt kopplas till familjens samhällsstatus och betydelsen av den biologiska principen. ${ }^{22}$

Den privata och relationella karaktären i familjevåldsproblematiken reser en del frågor om straffrättssystemets adekvata funktion, och aktualiserar också särskilda utmaningar. På kriminaliseringsnivå kan det diskuteras hur extensiv straffrätten ska vara, dvs. vilka handlingar ska definieras som straffbart familjevåld, som brott, och därmed kunna läggas till grund för straffprocess och straffverkställighet. Ska exempelvis en far som ger en örfil i uppfostranssyfte, eller en mor som tappar besinningen och våldsamt släpar sin utagerande son ut ur rummet, principiellt kunna straffas? Eller bör sådana situationer hanteras på annat sätt? 
Och hur ska i såfall straffrättens regler utformas för att ge adekvata och generellt tillämpbara gränsdragningar och definitioner? ${ }^{23}$ Och hur ska straffprocessens aktörer förhålla sig till straffreglerna $i$ konkreta beslut om att exemplevis påbörja eller underlåta efterforskning?

Sådana problemställningar kopplar till frågan om hur den potentiella intressekonflikten mellan straffrättens gärningsperspektiv - och fokus på effektiv normrealisering - och hänsyn till barnets bästa ska hanteras. Från perspektivet av barnets bästa finns uppenbara begränsningar i de brottsbekämpande myndigheternas sätt arbeta och straffprocess och straffverkställighet är kanske inte alltid förenligt med barnets intressen och behov.

Familjevåldsbrottets karaktär reser också mer generellt problem för systemet att att ge effekt åt rättens och straffrättens normer. Det är svårt för systemets aktörer att få kännedom om eller upptäcka brott och det är svårt att bevisa brott. De personliga och emotionella bindningar som ofta finns mellan förövare och offer kan göra det svårt för offret att vända sig till rättssystemet, eller till personer som inte ingår i en nära förtroendekrets. Systemets möjlighet att få kännedom om familjevåldsbrott mot barn präglas också ofta i stor grad av att barnen själva, särskilt om det är fråga om små barn, har begränsade resurser att själva initiera en straffsak. Också mera generellt har barn som utsätts för omsorgssvikt små möjligheter att skydda sig själva. ${ }^{24}$ Straffrättssystemets ingripande mot familjevåldsbrott mot barn förutsätter således, också i högre grad än vid motsvarande brott mot vuxna, att andra personer än de som själv utsatts för brottet för det till systemets kännedom. Familievåldsbrottets typiska lokalisering till familjen som en "privat« institution verkar här försvåra för allmänheten att anmäla brott. Det finns i vart fall undersökningar som tyder på att allmänheten orienterar sig efter en långtdragen försiktighetsprincip, av rädsla av att blanda sig i något privat och i värsta fall ställa till stora svårigheter i en familj. ${ }^{25} \mathrm{I}$ den mån missförhållanden anmäls sker detta dessutom ofta till barnevernet, och inte till straffrättssystemet. I fråga om att anmäla missförhållanden mot barn har anställda i offentliga institutioner därför en central roll och dessa är i vissa situationer också förpliktade att anmäla till barnevernet. Regelverket innehåller dock inga tydliga anvisningar för när barnevernet i sin tur ska aktualisera straffrättssystemet och reser generellt många frågor om hur anställda i offentliga institutioner ska förstå och tillämpa regler om tystnadsplikt, anmälningsrätt, anmälnings/upplysningsplikt och avärjningsplikt. $^{26}$

Samlat sett sätter familjevåldsbrottets komplexa karaktär således fokus på en rad problemställningar om straffrättssystemets funktion och begränsingar i familjevåldskontexten som ska försöka besvaras i det följande. Som en utgångspunkt 
för ett (försök till ett) sådant svar ska dock det perspektiv som det orienterar sig från klargöras.

\section{Perspektiv}

\subsection{Straffets rättfärdigande och nödvändighet}

En utgångspunkt för en diskussion om straffrättens funktion ifråga om att bekämpa familjevåld måste rimligen tas i mer generella ståndpunkter om straffrättens och straffrättssystemets funktion i samhället. Här företräds i korthet uppfattningen att straffrätten endast är ett bland flera medel för att bekämpa oönskat beteende. Straffet kräver dessutom på grund av sin särskilt ingripande karaktär ett särskilt rättfärdigande och ska som huvudregel användas som en sista utväg.

Straffets rättfärdigande kan förankras i argument i två olika »dimensioner« ${ }^{27} \mathrm{I}$ den ena dimensionen motiveras straff på deontologiska eller normativa grunder, $\mathrm{i}$ relation till klandervärdheten eller förkastligheten i en handling. Straffrätten kan i denna dimension förstås som samhällets »etiska kod«. Vissa handlingar är helt enkelt så klandervärda att det framstår som otänkbart att inte möta dem med klander och straff - som exempelvis allvarligt våld mot barn.

I den andra dimensionen rättfärdigas straff typiskt sett i relation till nyttoargument som rör sig på en empirisk snarare än en normativ nivå. Straff kan här anses rättfärdigt om det utgör ett effektivt sanktionsmedel och andra medel inte är tillräckliga för att skydda ett givet rättsligt intresse.

Olika straffrättsteorier betonar i olika grad dessa olika dimensioner, men erkänner ofta båda dimensionernas relevans för att förklara straffrättens innehåll. Det är också tydligt att gällande norsk straffrätt betonar både nytta och klander som grunder för straffet. ${ }^{28}$ Vissa handlingar, såsom trafikbrott, straffas mera för att styra beteende medan andra, såsom våldsbrott mot barn, framhävs som straffbara enbart i kraft av sin klandervärdhet. Klandervärdhet »trumfar« i slutänden dock ofta nyttobetraktningar, så att straff i bland kan rättfärdigas oavsett om det kan finnas andra mer konstruktiva reaktioner. Det problematiska är dock hur avvägningen mellan nytta och klander ska göras i de fall där klandervärdheten inte är uppenbar och där det också finns skäl att tro att straffrättssystemet kan vara kontraproduktivt i relation till de intressen som ska skyddas.

I detta avseende reser familjevåldsbrott mot barn särskilda problemställningar. Som utgångspunkt verkar det givet att straffrättssystemet ska aktualiseras vid familjevåld mot barn, som en uppenbart klandervärd handling. Samtidigt kan det problematiseras om det bakomliggande intresset för straffrättens reglering om sådant våld - att skydda barnet - alltid bör realiseras genom straffrättsligt ingripande. Straffrättens hot om straff - och då ofta fängelsestraff för den som utövat 
våld - verkar i vissa fall kunna hindra en effektiv realisering av de aktuella normerna och ibland även gå emot barnets egna önskningar och behov. I de mindre allvarliga fallen finns också moraliska och kulturella kontroverser i frågan om straffrättens nödvändighet och legitimitet. Dessutom samexisterar straffrättssystemet i denna kontext med institutioner som också syftar till att verka för barnets bästa och som i bland kanske har mer adekvata medel för att skapa en bättre situation för familjen och barnet. Därför måste straffrättens funktion i familjevåldskontexten också diskuteras i ett vidare systemperspektiv.

\subsection{Systemperspektivet som infallsvinkel till familjevåldsproblematiken}

Det systemperspektiv som företräds som infallsvinkel till familjevåldsproblematikent är på ett grundläggande plan orienterat mot brottsprevention. ${ }^{29}$ Det bygger på tanken att straffrättsystemet som helhet har som syfte att, parallellt med andra institutioner, bidra till att bekämpa och oönskat samhälleligt beteende. Här finns också en (effektivitets-)förväntan på systemet att det i tillräcklig grad realiserar givna målsättningar - en förväntan som mera konkret kan uttryckas i termer av tillräcklig hög grad av upptäckt eller uppklaring av brott, tillräckligt hög genomströmningstid i domstolarna, korta soningsköer etc.

Systemperspektivet omfattar dock både en extern och en intern dimension. Den externa dimensionen refererar till straffrättssystemets externa sociala kontext och till de medel som är tillgängliga som alternativ till kriminalisering och straff. Detta perspektiv är därför $\mathrm{i}$ första hand relevant att belysa $\mathrm{i}$ en diskussion om starffrättssystemet överhuvudtaget ska aktualiseras, dvs. i frågan om kriminalisering. Det externa perspektivet måste dock också förstås som ett perspektiv för straffrättssystemets interna aktörer, i fråga om att kontinuerligt värdera en möjlig samverkan med andra institutioner som existerar parallellt med straffrättssystemet, såsom exempelvis barnevernet.

Det interna perspektivet är i första hand relevant att diskutera inom ramen för existerande straffrättsregler. Detta perspektiv flyttar således fokus från frågan om kriminalisering är adekvat till frågor om hur brott mot givna kriminaliseringar ska hanteras i beslutsfattande på andra nivåer i straffrättssystemet, dvs. i efterforskning, åtalsbeslut, utdömande av skuld och straff och straffverkställighet. I vad mån finns exempelvis utrymme för undantag eller reservationer från den materiella straffrättens generella utgångspunkter? Som en fråga för lagstiftaren flyttar det interna perspektivet fokus till frågor om straffprocessens och reaktionssystemets innehåll.

Systemperspektivets tillämpning bygger på kunskap om vilka (interna och externa) medel som faktiskt står till förfogande i en given problemkontext och vil- 
ken funktion de kan ha. Den integrerar också en tidsdimension och en nödvändig distinktion mellan kortsiktiga och långsiktiga strategier för måluppfyllande - i det här fallet att bekämpa familjevåld. Det finns ingen principiell motsättning mellan dessa olika strategier och båda kan - och bör ofta - användas samtidigt som brottsbekämpande och brottsförebyggande åtgärder.

Kortsiktiga strategier fokuserar typiskt sett på att lösa ett konkret problem omedelbart. Sådana kortsiktiga lösningar på familjevåldsproblem kan ta många former. Framställningen begränsas här till att diskutera sådana »lösningar« i relation till medel som siktar till att förhindra eller avbryta konkret och pågående våld. Straffrättssystemet förfogar här över de traditionella medlen att kriminalisera, utdöma och verkställa straff och kanske mer centralt över olika straffprocessuella tvångsmedel. De kanske mest välkända kortsiktiga strategierna för brottsprevention är avskräckning och inkapacitering, som siktar till att verka omedelbart.

Det är dock från ett straffrättsligt systemperspektiv särskilt intressant att värdera funktionen av andra institutioner, som opererar parallellt med och ibland också inom straffrättssystemet. Det finns i detta avseende många tänkbara institutioner som kan gripa in i en våldssituation och ta ansvar för att den ska upphöra, såsom anställda på skolor och dagis, läkare, grannar och alla andra som blir uppmärksamma på missförhållanden mot barn.

En särskilt central institution är emellertid barnevernet. Barnevernet har också ett huvudansvar i samhället ifråga om att säkra att barn och unga får trygga uppväxtvillkor. ${ }^{30}$ Fokus för barnevernet ligger, med andra ord, på att verka för barnets bästa. För att fylla sin funktion har barnevernet också rättsligt mandat att företa olika åtgärder som syftar till att främja en bättre familje- eller omsorgssituation för barnet. Våld eller kränkningar mot barn som straffrättsligt definieras som brott utgör i detta avseende en omsorgsproblematik som generellt sett förutsätter ingripande och uppföljning av barnevernet. Som den mest ingripande åtgärden kan barnevernet besluta om att överta omsorgen av barnet, för placering i fosterhem, institution eller behandlingscenter. ${ }^{31}$

Långsiktiga strategier tar istället ett utvecklingsperspektiv och ser till lösningar över tid. Långsiktiga strategier har ännu tydligare koppling till andra medel än de strikt straffrättsliga. När vi rör oss in i denna domän, rör vi oss också in i mer komplexa värderingar av vad som fungerar för att reducera kriminalitet. Brottsprevention kräver, som det överordnade målet för straffrättssystemet, generellt att systemets möjliga funktion värderas i relation till vad som kan uppnås genom andra strategier än kriminalisering och straff. Detta är ett komplext tema som inte ska utvecklas närmare här. Det enda argumentet som ska framhävas är att det är viktigt att se att straffrättssystemets interna strategier av kriminalisering och straff 
och straffprocessuella tvångsmedel har tydliga begränsingar i fråga om att skapa långsiktiga och varaktiga förändringar för ett samhälles kriminalitet. Externa strategier, såsom utbildning och andra välfärdsåtgärder, har ofta en avgörande betydelse. I familjevåldskontexten verkar det inte minst finnas ett visst samband mellan dålig social integrering, rusproblematik och våld. ${ }^{32}$

Mot denna bakgrund ska nu några konkreta reflektioner - svar? - om straffrättssystemets adekvata roll och dess begränsingar i familjevåldskontexten framhävas. För tydlighetens skull görs en diskinktion mellan de »uppenbara« fallen av våld och »de mer komplexa«.

\section{Svar? Straffrättssystemets funktion i familjevålds-kontexten?}

\subsection{Hanteringen av de »uppenbara « fallen}

Vi startar med de »uppenbara« fallen. Detta är de fall av tydligt våld som paradigmatiskt måste lokaliseras i straffrättens kärna. Med tanke på den särskilda klandervärdhet som finns $i$ våld mot barn måste kriminalisering av sådant våld accepteras utan reservationer. I förarbetena framhävs också barn, dvs. personer under 18 år, som en särskilt sårbar grupp, som generellt befinner sig i en beroendesituation. Familjevåldsbrott mot barn anses utgöra ett grundläggande svek mot barnet, och värderas som utgångspunkt allvarligare än motsvarande brott mot vuxna, eftersom »den som i utgangspunktet skal yte omsorg, er den som påfører smerte ${ }^{33}$

Också ett nyttoorienterat brottspreventivt perspektiv ger argument för kriminalisering. Privata initiativ verkar generellt otillräckliga som alternativ till kriminalisering. Som minimum, krävs existensen av ett institutionaliserat och formaliserat system som har offentligt ansvar och kompetens att ingripa i fall av familjevåld. I Norge är den mest relevanta institutionen barnevernet. Kan då det brottspreventiva argumentet ge skäl att helt lämna familjevåld i händerna på sådana institutioner?

Det är här intressant att notera att norsk rätt inte uppställer några förpliktelser för offentliga institutioner att rapportera familjevåld mot barn till straffrättssystemet, utan bara till barnevernet. Och från barnevernets perspektiv verkar avgöranden om polisanmälan bero på vad som anses vara för barnets bästa. Det är dock svårt att avgöra vad som är barnets bästa. Straffrättssystemet förfogar över en rad straffprocessuella tvångsmedel som i bland är nödvändiga för att ingripa i en hotande situation för ett barn. ${ }^{34}$

Den allvarliga karaktären i familjevåldsbrottet, i kombination med att detta brott ofta sker i det fördolda ger vidare argument för att straffrättssystemet ska aktualiseras. Straffrättssystemets aktörer är sannolikt de mest professionaliserade 
i fråga om att efterforska brott. Enligt Europadomstolens praxis måste straffrättssystemets ingripande också ses mot bakgrund av systemets normskapande och därmed brottspreventiva effekt i samhället. ${ }^{35}$

Totalt sett finns i de klara fallen således inte någon konflikt mellan deontologiska argument om klandervärdhet och nyttoargument om brottsprevention. Vi star således kvar med ett starkt argument för kriminalisering. Av samma skäl bör straffrättssystemets aktörer verka för en effektiv realisering av straffrättens regler.

I detta avseende kan den speciella regleringen som ges av strl. § 219 ses som ett steg framåt för norsk straffrätt. Även om många av de kränkningar som denna bestämmelse omfattar också täcks av andra bestämmelser är det av värde att ha en egen regel för familjevåldsbrott. Genom att framhäva familjevåld som ett särskilt brott kommer detta brott också i fokus för de brottsbekämpande myndigheterna - och ger en särskild rättslig bas för att prioritera effektiv normrealisering. Funktionen av strl. § 219 reflekteras i detta avseende i det faktum att många av de fall av »familjevåld« som registreras av polisen faktiskt »upptäcks« internt genom en omklassificering av andra fall som inte från början rapporterades som familjevåldsfall utan kanske som bråk, rus etc. Det kan däremot diskuteras om utformningen av strl. § 219 är adekvat. Är den exempelvis för långtgående i fråga om de handlingar den omfattar? Borde den delas upp i flera bestämmelser så att exempelvis familjevåldsbrott mot barn regleras separat? Vissa aspekter av dessa frågor diskuteras vidare nedan.

Det faktum att straffrättssystemet måste involveras i de klara fallen utesluter givetvis inte heller att andra institutioner också kan involveras, som externa och kanske mer långsiktiga brottspreventiva strategier. Tvärtom verkar sådana strategier vara nödvändiga för att bibehålla en moderat och defensiv straffrätt. Det straffrättssystemet kan uppnå är ganska begränsat och utan parallellt brottsförebyggande arbete är risken sannolikt högre att kriminalisering överanvänds som ett relativt kortsiktigt och billigt medel. Barnevernet, eller andra aktörer på fältet, har också inom ramen för pågående processer större förutsättningar att följa upp och ta vara på barnet som individ - och även att se till familjens bästa som helhet. En efterforskning av brott är dessutom ofta tidskrävande och det är långt i från säkert att den leder till åtal och vidare process. Barnevernet har i detta avseende, också mot bakgrund av de beviskrav som präglar straffrätten, större möjligheter att $\mathrm{i}$ slutänden gripa in och förändra en situation där barn far illa. Det är därför viktigt att understryka betydelsen av barnevernets roll även i ärenden där någon straffrättslig efterforskning inte inleds, läggs ner, eller vid friande dom. 


\subsection{Hanteringen av de komplexa fallen}

Familjevåld omfattar inte bara uppenbara fall, utan i stor grad också komplexa fall. Straffeloven $\S 219$ kan härvid omfatta en rad olika brottsliga handlingar, av olika komplex karaktär, som också kan variera väsentligt i innehåll och grovhet. Därtill kommer de handlingar som kan omfattas av övriga aktuella bestämmelser i straffeloven. De fall som här omtalas som »komplexa fall« karakteriseras av en kombination av våldets karaktär, i fråga om att vara mindre allvarligt, och familjevåldsbrottets relationella kontext. I många av dessa fall kan det finnas tvivel om det bästa för barnet är att involvera straffrättssystemet.

Frågan är då om mer komplexa fall av familjevåld inte ska göras till föremål för kriminalisering, så att viss kritik kan riktas mot den relativt sett extensiva omfattningen av gällande straffbestämmelser och rådande rätts fokus på straff och sanktioner. Givet att kriminalisering som sådan kan anses nödvändig kan frågor istället resas på andra nivåer av straffrättssystemet, i fråga om huruvida det ska finnas utrymme för undantag och moderationer i konkreta fall i efterforskning, åtalsbeslut, straffmätning och påförljdsval och straffverkställighet.

Att avstå från kriminalisering är svårt att försvara även i de komplexa fallen. Argumentet om klandervärdhet träffar på ett genellellt plan alla fall av familjevåldsbrott mot barn. Norsk rätt har också just mot denna bakgrund utvidgat området för kriminalisering, genom infogandet och ändrandet av strl. § 219. Det brottspreventiva argumentet ger också skäl för att alla former av familjevåld mot barn ska vara föremål för hot om straff. Det verkar också stå i strid med grundläggande straffrättsliga principer att göra kriminaliseringars omfång beroende av vad som är bäst för familjen eller barnet. Frågan är då om det är adekvat att ge utrymme för att göra undantag och reservationer på andra nivåer i systemet i de fall där argument om barnets bästa motiverar det - och i så fall hur.

Från straffrättens perspektiv är det i strikt mening bara straffrättssystemet som ska hantera familjevåldsbrott och alla sådana brott ska också principiellt sett hanteras straffrättsligt. Från straffrättens brottsbekämpande perspektiv kan aldrig hänsyn till barnet, i meningen barnets individuella intressen, få förtur framför den straffrättsliga målsättningen att realisera aktuella brottsbestämmelser. Straffrätten ska tillämpas objektivt, lika för alla och med iakttagande av proportionaliet mellan brott och straff. Huruvida exempelvis ett barn inte önskar sin far eller mor i fängelse, eller huruvida straff är mindre väl lämpat än andra åtgärder för att förebygga ny brottslighet är i hög grad irrelevant från straffrättssystemets brottsbekämpande perspektiv. Barnets bästa kan emellertid inom systemet i slutänden bara förstås och realiseras inom de ramar som sätts av straffrättens normer och utgångspunkter om realisering av dessa. Hänsyn till barnet, och till familjen, är 
relevanta också i straffrättens kontext och söks tillgodosedda exempelvis genom varsamhet i förhör med barn, anhållande av misstänkta familjemedlemmar och omhändertagandet av de barn som drabbas.

Samtidigt kan det inte uteslutas att straffrättsligt ingripande i vissa särskilt komplexa fall är ett sämre alternativ än andra tillgängliga medel, såsom exempelvis ingripade av barnevernet. Straffets och särskilt fängelsestraffets potentiellt destruktiva karaktär är i detta avseende väldokumenterad. Mot denna bakgrund och med barnets bästa som argument - kan också barnevernet välja att inte rapportera ett misstänkt (mindre allvarligt) brott till polisen.

Dessutom stadgar barnkonventionens artikel 12 att barn ska ha rätt att uttrycka sin syn, och att denna ska tilläggas behörig vikt i samsvar med barnets ålder och mognad. ${ }^{36}$ FNs komitée för övervakande av barnkonventionens efterlevnad ${ }^{37}$ har i denna förbindelse uttalat att en straffprocess mot föräldrarna sällan är till barnets bästa och argumenterat för barns inflytande på åtalsbeslut. ${ }^{38}$ Att låta barnet på detta sätt få inflytande i straffprocessen går i viss grad på tvärs mot utgångspunkterna i norsk rätt, men framhäver likväl intressanta perspektiv. Mer generellt är det intressant att realiseringen av skyddsintresset bakom kriminalisering mot familjevåld, att skydda barnet, åtminstone delvis kan hindras i straffrättssystemets implementering av de samma reglerna. Straffrättssystemet riskerar med andra ord att i slutänden bli kontraproduktivt.

Mot denna bakgrund verkar det rimligt att problematisera om barnets bästa i familjevåldskontexten i större grad än i nuläget ska styra reglering och beslutsfattande på olika institutionella nivåer i straffrättssystemet. Kan man exempelvis tänka sig regler som explicit stadgar om åtalsunderlåtelse när barnets bästa motiverar det, så att större utrymme skapas för att hantera problematiken genom andra åtgärder än de straffprocessen traditionellt förfogar över? Eller kan man tänka sig alternativa procedurer, som konfliktråd, som generella alternativ till straff i dessa fall? Norsk rätt medger som framkommit redan barnets bästa som ett argument för att verkställa en dom på fängelsestraff genom soning hemma.

När man överväger sådana frågor, som i slutänden handlar om utrymmet för alternativa medel till straffrättsligt ingripande, tvingas man tillbaka in i den svåra frågan om avvägningen mellan en handlings klandervärdhet och nyttan av straff. Om vi har skäl att tro att den brottspreventiva effekten i fråga om familjevåld i stor grad går genom andra medel än straffsanktioner, som kanske till och med kan vara kontra-produktiva, ska vi då fortsätta att argumentera för straffrättssystemets nödvändiga inblandning bara på grund av handlingens moraliska klandervärdhet? Och om vi skulle önska det, kan vi medge reservationer för barnets bästa utan att komma i konflikt med grundprinciper om jämlikhet och objektivi- 
tet? Vi kan inte heller bortse från den svårighet som finns i att familjevåld sker i det fördolda och att det därför kan vara svårt att bedöma hur allvarligt ett konkret tillfälle faktiskt är.

\subsection{Allmänna slutsatser}

Det verkar i slutänden saknas klara svar på dessa svåra dilemman mellan klandervärdhet, proportionalitet och brottspreventiv framgång. Saken är komplex eftersom den också involverar den sociala dimensionen av medborgarnas attityder - den s.k. »allmänna rättskänslan«. En allmän avslutande ståndpunkt är likväl att det är viktigt att skilja mellan olika nivåer i systemet i fråga om genomslaget av mer individuella hänsyn, i relation till straffrättens grundprincipper om objektivitet och jämlikhet. Från en internrättslig synvinkel har sådana hänsyn litet utrymme i kriminalisering. På den processuella nivån verker dock utrymmet bli större - vilket också syns i det faktum att individualpreventiva argument anses relevanta i straffmätning och påföljdsval. Slutligen på straffverkställighetsnivån, blir utrymmet för individuella betraktningar ännu större. I dag är det åtminstone generellt accepterat att straffverkställighet ska orientera sig mot den straffdömdes individuella rehabilitering och samhällsreintegration. Med andra ord, gränserna som kan härledas från straffrättens grundprinciper om objektivitet och jämlikhet verkar variera mellan de olika nivåerna i systemet. Mot denna bakgrund ska vi inte heller förhastat utesluta att straffrättssystemets funktion helt ska förstås som liktydigt med kriminaliseringars påbud. Under alla omständigheter måste vi nog tänka förbi traditionella lösningar, och i större grad orientera oss mot ett vidare systemperspektiv för att komma vidare framåt i familjevåldsproblematiken. Komplexiteten i detta problem pekar också under alla omständigheter på vikten av en parallell involvering - och samverkan - mellan straffrättssystemet och andra institutioner.

\section{Noter}

1. Linda Gröning, Juris Dr. (Lund 2008), numera professor vid det juridiske fakultet, Universitetet i Bergen med ett forskningsengagement inom forskningsprojektet »strafferettssystemets funksjonalitet«.

2. Se vidare nedan i avsnitt 2 .

3. Detta perspektiv presenteras i avsnitt 3.2.

4. Jfr. t.ex. den senaste handlingsplanen Et liv uten vold: handlingsplan mot vold i noere relasjoner 2014-2017 s. 4.

5. Se vidare nedan $i$ avsnitt 2.2 om familjevåldsbrottets karaktär.

6. Se bl.a. NOU 2003:31 s. 61, Ot.prp. 104 (2008-2009), särskilt kap. 6, Ot.prp. 22 (20082009) s. 177. 
7. För innebörden av barnets bästa, se Haugli, «Hensynet til barnets beste« i Barnekonvensjonen: barns rettigheter $i$ Norge Sandberg m.fl. (red.), (Oslo, 2012), s. 51-72. Se även Sandberg, Barnets beste: Om barnefordeling, rettspraksis og rettferdighet (Oslo 1990).

8. Se vidare Ot.prp. 104 (2008-2009), särskilt avsnitt 6.7. Jfr. också A. v. the United Kingdom, judgement of 23 september 1998, RJD 1998 s. 2692, angående barns skydd mot »lättare« fysisk bestraffning. Bestämmelsen ändrades $2010 \mathrm{i}$ syfte att klargöra att barn inte făr utsättas för någon form av våld, inte heller »lette klaps«, även om denna sker som ett led i barnuppfostran. Se Ot.prp. 104 (2008-2009), avsnitt 6.1. Jfr. också Ot.prp. 22(2008-2009) s. 177.

9. Se Rt. 2005 s. 1567, i avsnitt 24. Se även Backer, »Kan foreldrene gi barna en »lett klaps«?« i Festskrift til Carl August Fleischer (Oslo 2006) s. 57-75.

10. För en närmare redogörelse av denna bestämmelse, se Matningsdal, Norsk spesiell strafferett (Oslo 2010) del III, kap. 13.

11. Se Ot.prp. 113 (2004-2005) s. 36-37, se även Rundskriv från Riksadvokaten nr. 3/2008, punkt V. 2.

12. Jfr. även Rt 2010 s. 129 i avsnitt 12 där det faktum att barn varit vittne tillmättes särskild vikt vid bedömningen av kränkningar av mor.

13. Se Ot.prp. Nr. 113 (2004-2005) s. 45. Se även Rt. 2005 s. 938 i avsnitt 4 och Rt. 2007 s. 1537 i avsnitt 20.

14. Se Ot.prp. nr. 113 (2004-2005) s. 45-46.

15. Se LOV 2005-05-20 nr 28: Lov om straff (straffeloven), §§ 282-283.

16. Se Riksadvokatens rundskriv nr. $3 / 2008$ punkt II, samt nr. 1/2008 punkt IV.

17. Se Prop. 116 L (2009-2010) s. 19-20.

18. Se t.ex. Elvegård m.fl., Tilrettelagde samtaler ved familievold, evaluering av familievoldprosjektet til Konfliktrådet i Trondheim (2011).

19. Jfr. Strgjfl. § 3, med tillhörande forskrift $§ 1-3$.

20. NOU 2003: 31 s. 62. Se även bl.a. Rt. 2011 s. 34 i avsnitt 28 och Rt. 2004 s. 595 i avsnitt 17.

21. Denna problemställning har bl.a. framhävts i NOU 2012: 15, Politikk for likestilling, avsnitt 14.2.3.

22. Se om den biologiska principen och dess betydelse i barnevernssaker i NOU 2012: 5, Bedre beskyttelse av barns utvikling: Ekspertutvalgets utredning om det biologiske prinsipp i barnevernet.

23. Det är här ett grundproblem hur våld i nära relationer som pågår över flera år och skapar en situation som har konsekvenser som sträcker sig långt utöver den konkreta våldshandlingen egentligen ska begripas, regleras och sanktioneras.

24. Se t.ex. Andersen, «Melde- og opplysningsplikt overfor barnevernstjenesten», FAB nr. $1 / 2008$ s. 28.

25. I en undersökning från Redd barna framkom att en vanlig orsak till att privatpersoner inte gjorde något vid stark misstanke om våld mot barn var att de inte ville lägga sig $\mathrm{i}$; se Undersøkelse om fysisk og psykisk vold og overgrep mot barn og ungdom, genomförd för Redd barna av Synnovate MMI, 12 december 2006, tillgänglig via http://www.reddbarna.no.

26. Se Gröning, «Familjevåld i gränssnittet mellan straffrätten och barnevernsrätten: Om offentliga myndigheters rätt och plikt att anmäla brott«, TfS, nr. 1/2013 för en diskussion kring dessa problemställningar. 
27. För de olika positionerna och deras filosofiska fundament, se bl.a. R.A. Duff \& D. Garland, »Introduction: Thinking about Punishment « i A Reader on Punishment, R.A. Duff \& D. Garland, eds., (Oxford 1994) s. 2-8.

28. Se vidare i L. Gröning, «Sraffrätten som en del av straffrättssystemet: principförklaring av fängelsestraffets inenhåll», TfR nr. 1/2013, avsnitt 6.3 .

29. Grunderna för detta systemperpektiv har utvecklats i Gröning, the Criminal Justice System: Meaning, Concept, Function (manuskript 2013).

30. Jfr barnevernsloven $\S 1-1$. Angående barnevernets funktion se vidare Stang, «Barns rett til familie og omsorg, særlig om barnevernet« i Barnekonvensjonen: barns rettigheter i Norge, s. $157-185$.

31. Jfr barnevernsloven § 4-12, 4-14.

32. För en utredning av olika förklaringsmodeller, se bl.a. NOU 2003: 31, Retten til et liv uten vold, kap. 3.

33. NOU 2003: 31 s. 62.

34. För en närmare beskrivning av regleringen kring offentliga myndigheters rätt och plikt att anmäla brott och frågan barnets bästa i detta sammanhang, se Gröning «Familjevåld i gränssnittet mellan straffrätten och barnevernsrätten: Om offentliga myndigheters rätt och plikt att anmäla brott«, särskilt avsnitt 3 .

35. Jfr. bla. Opuz v. Turkey, judgment of 9 June 2009 (application no. 33401/02) där domstolen fastslog kränkning av artiklarna 2, 3 och 14 på grund av att straffrättssystemet inte effektivt förhindrat grovt familjevåldsbrott.

36. Se vidare Søvig Barnets rettigheter på barnets premisser - utfordringer i møtet mellom FNs barnekonvensjon og norsk rett, Det juridiske fakultets skriftserie nr. 115 (Bergen 2009) s. 47-88 om barnkonventionen art. 12 .

37. The committee on the rights of the child, se http://www2.ohchr.org/english/bodies/crc/ för information.

38. Se General comment no. 8 (2006) avsnitt 40-46, se vidare Søvig (2009) s. 142-144. 